УДК: 376:159.922.76

DOI: $10.35619 /$ iiu.v1i10.165

Косарєва Галина

кандидат педагогічних наук, доцент кафедри педагогіки та психології (дошкільної та корекційної) імені проф. Т. І. Поніманської Рівненського державного гуманітарного університету м.Рівне, Україна

ORCID: 0000-0002-1999-5787 e-mail: galochka0961@gmail.com

\title{
ФОРМУВАННЯ ТОЛЕРАНТНОГО СТАВЛЕННЯ ДО ДІТЕЙ З ОСОБЛИВИМИ ПОТРЕБАМИ У МАЙБУТНІХ ЛОГОПЕДІВ
}

Анотація. У статті 3 метою мотивації дослідження проблеми формування толерантного ставлення до дітей $з$ особливими потребами у майбутніх логопедів розкрито сутність педагогічної толерантності як характеристики професійної діяльності майбутнього фахівця спеціальної освіти. Визначена роль професійної компетентності майбутнього педагога у формуванні зазначеної якості. Зазначено, що цінності та толерантність майбутнього педагога становлять фундамент професійної компетентності, а предметним полем формування цінностей та толерантності $\epsilon$ культура. Проаналізовано досвід зарубіжних дослідників та різні підходи вітчизняних науковців щодо формування у майбутнього логопеда милосердя, терпимості, смиренності, чесності, доброти, гуманності і таке ставлення до дитини 3 особливими потребами, в якому немає осуду, але є співчуття, співпереживання, розуміння цінності людської особистості та бажання допомогти. Висвітлено значення педагогічної толерантності для сучасної педагогічної науки. Визначено місце толерантності в системі гуманістичних цінностей, виокремлено головні риси толерантного педагога. На основі узагальнених результатів дослідження виокремлено професійні та особистісні риси майбутнього логопеда, що впливають на формування толерантного ставлення до дітей з особливими потребами.

Ключові слова: толерантність, педагогічна толерантність, формування толерантності, толерантне ставлення, діти 3 особливими потребами, гуманність, милосердя, майбутні логопеди, загальнолюдські цінності.

Постановка проблеми. В умовах кардинальної перебудови, модернізації та відродження національної системи освіти в Україні, спрямованої на демократизацію, духовність та гуманізацію, особливої актуальності набуває проблема, зумовлена необхідністю переорієнтації підходів до реалізації завдань спеціальної педагогіки.

Слід зазначити, що найбільш актуальною в аспекті спеціальної освіти $\epsilon$ проблема мовленнєвих розладів у дітей з особливими потребами.

Зауважимо, що логопеди є єдиними фахівцями у проведенні оцінки, діагностики i корекції мовленнєвих порушень. Логопед - педагог, який здійснює навчальну, корекційну, відновлювальну, реабілітаційну роботу з дітьми, які мають мовленнсві порушення. Логопед вивчає та фіксує динаміку розвитку дитини, створює сприятливі організаційно-педагогічні умови для дітей із тяжкими мовленнєвими порушеннями (ринолалією, заїканням, дизартрією, алалією, афазією); виробляє оптимальну педагогічну й корекційну стратегію; обирає ефективні форми, методи і засоби корекційно-відновлювального процесу.

На цьому тлі особливо важливим $є$ питання про те, яким має бути майбутній логопед в нових умовах, яким вимогам має відповідати його професійна педагогічна діяльність. 
Вирішення поставлених завдань, на нашу думку, значною мірою залежить від професіоналізму вчителя-логопеда, його культури, поваги до дитячої особистості; осмислення своєї ролі організатора і наставника; уявлення про дитину як про саме цінне; усвідомлення того, що кожна дитина унікальна; особистісних якостей та гуманістичних цінностей: моральності, духовності і толерантності.

Аналіз останніх досліджень 3 проблеми. Як свідчить аналіз наукових праць, проблеми толерантності досліджувалася в різних напрямах: проведено теоретичний аналіз поняття «толерантність» 3 позиції філософії (Х. Аквінський, Платон, Вольтер, Г. Гегель, І. Кант, М. Ганді, Г. Зиммель, Г. Сковорода, Р. Валітова, В. Лекторський), психології (О. Асмолов, Г. Балл, О. Леонтьєв та ін.), визначено шляхи формування окремих видів толерантності (В. Бойко, О.Грива, І. Гриншпун, А. Жадан, Н. Лебедєва). Проблеми толерантності, безконфліктності, тактовності перебували в полі зору таких вітчизняних дослідників, як Т. Алексєєнко, О. Безпалько, Н. Заверико, I. Звєрєва, А. Капська, О. Олексюк, В. Петрович, С. Савченко. Толерантність деякими авторами ототожнюється 3 поняттям терпіння (Ісаєва та Комарова, 2003), терпимості (Реан, 1999), проміжним етапом між терпимістю і нетерпимістю (Клепцова, 2004).

Виходячи зі специфіки теми дослідження, поділяємо думку Б. Вульфова про те, «що толерантність як особистісну якість потрібно розвивати у процесі навчання, виховання, взаємодії, коли відбувається взаємне збагачення досвіду толерантності, що створює емоційно-інтелектуальне та моральне поле, на грунті якого виростає позитивний досвід стосунків і спілкування. Наявність і створення такого поля відповідальне завдання і досягнення педагога» (Вульфов, 2002).

Щодо розкриття педагогічного контексту феномена толерантності, вважаємо суттєвим відзначити, що у роботах окремих авторів (І. Бех, Л. Завірюха, В. Калошин, B. Рахматшаєва, В. Шалін,) педагогічний контекст феномена толерантності розглядається не тільки як характеристика індивідуальної свідомості, але й як особлива особистісна риса, що може бути більшою або меншою мірою сформована відповідною педагогічною взаємодією (Тодоровцева, 2004).

Отже, слід відзначити, що толерантність, будучи особливістю свідомості чи особистісною рисою, не притаманна людині спочатку і може ніколи не з'явитися, якщо не буде спеціально вихована, сформована.

Таким чином, аналіз літератури 3 теми дослідження та особлива актуальність проблеми формування толерантного ставлення до дітей з особливими потребами у майбутніх логопедів, професійного становлення вчителя-логопеда як носія демократичних цінностей та толерантної особистості, а також недостатній рівень розробленості іï теоретичного, методичного й прикладного аспектів зумовили вибір теми статті.

Мета статті: дослідження проблеми формування толерантного ставлення до дітей 3 особливими потребами у майбутніх логопедів.

Виклад основного матеріалу дослідження. Проблема формування толерантного ставлення до дітей з особливими потребами у майбутніх логопедів досить складне і багатоаспектне явище, яке вимагає значних зусиль педагогічних колективів вищих навчальних закладів щодо виховання професійної честі сучасного корекційного педагога на принципах терпимості до чужих позицій, цінностей, взаєморозуміння, здатності до компромісу, милосердя.

Професійна підготовка логопедів до роботи 3 дітьми 3 різноманітними мовленнєвими порушеннями реалізується через якісне формування їх гуманістичного світогляду та громадянського становлення особистості, яке здійснюється у процесі навчально-пізнавальної діяльності, 3 урахуванням особливостей інтелектуального розвитку.

Толерантність передбачає установку майбутнього логопеда на прийняття особистості дитини з мовленнєвими порушеннями, на розуміння цієї дитини, на відверте спілкування. В основі толерантності $є$ повага до особистості дитини, терпляче 
ставлення до найрізноманітніших проявів цієї особистості, до іiі поглядів і навіть помилок та недоліків. Це означає - ставлення до дитини з особливими потребами, в якому немає осуду, але є співчуття, співпереживання, розуміння цінності людської особистості та бажання допомогти.

Тому важливим завданням вищої педагогічної освіти $є$ виховання фахівця, який відрізняється, насамперед, толерантністю і терпимістю до різних думок, поглядів і переконань, неупередженістю у ставленні до колег, дітей і подій, духовно-ціннісною мотивацією, гуманістичною спрямованістю, психологічною культурою, здатністю до професійної ідентифікації.

Власний досвід викладання у педагогічному виші дозволяє зробити висновок, що більшість студентів мають недостатній рівень розуміння самого поняття «толерантність», що вони не повною мірою усвідомлюють значущість толерантності в сучасному суспільстві. А, отже, ми можемо говорити лише про часткову сформованість готовності майбутніх логопедів до толерантної взаємодії з усіма учасниками педагогічного процесу.

Педагогічна проблематика формування толерантного ставлення до дітей 3 особливими потребами у майбутніх логопедів, на нашу думку, полягає в розкритті способів формування цього феномену, так як його сутнісні характеристики як ціннісного ставлення особистості до інаковості іншого здатні проявитися лише в динамічному, процесуально-дієвому аспекті.

Педагогічна толерантність - це володіння вміннями й навиками толерантної взаємодії з усіма суб'єктами освітнього процесу. Педагогічна толерантність $\epsilon$ соціальною категорією й проявляється в установці на прийняття іншої людини, на емпатійне розуміння, на відкрите й довірливе спілкування. Педагогічна толерантність може бути виражена через соціокультурний підхід і обов'язково пов'язана із процесом спілкування.

У межах професії толерантність виступає інтегральною характеристикою, яка визначає спрямованість і принципи взаємодії фахівця з оточуючими, залученими до сфери його професійної діяльності. Тобто професійна толерантність виявляється у межах професійної діяльності особистості, ії позиції і діях стосовно інших особистостей, залучених до сфери цієї діяльності (Ірхіна, 2009).

Позитивне розуміння толерантності може бути досягнуто й через усвідомлення іiі протилежності - інтолерантності або нетерпимості. На думку Т. Білоус, «нетерпимість базується на переконанні, що твоя група, твоя система поглядів, твій спосіб життя стоять вище за інших. Це не просто відсутність почуття солідарності, це неприйняття іншого через те, що він виглядає інакше, думає інакше, чинить інакше, навіть просто через те, що він існує» (Білоус, 2004). Нетерпимість призводить до панування та знищення, відмовляє у праві на існування тому, хто дотримується інших поглядів, визнає перевагу, придушення, а не переконання.

Шлях до толерантності - серйозна емоційна, інтелектуальна праця і психічне напруження. Це можливо лише на основі зміни самого себе, своїх стереотипів, власної свідомості. Майбутній логопед мусить бути не лише сам толерантний, а й готовий до виховання культури толерантності у своїх маленьких вихованців. Виховання в дусі терпимості має бути спрямоване на протидію впливу, що викликає почуття страху та відчуженості у ставленні до інших. Воно має сприяти формуванню у майбутніх логопедів навичок незалежного мислення, критичного осмислення i формування суджень, заснованих на моральних цінностях. Саме виявлення майбутнім логопедом толерантності $\epsilon$ вагомим виховним фактором. Давно відомо, що особистість формується особистістю, духовність - духовністю, а толерантність - толерантністю.

Вища школа $є$ одним із найважливіших інститутів виховання толерантності, що розглядається як співпраця й дух партнерства під час організації діяльності вищих навчальних закладів; готовність прийняти думку іншого члена колективу; визнання різноманітності; формування культури діалогу; відмова від домінування й заподіяння 
шкоди; повага до людської гідності тощо. Будь-які вияви нетолерантності, що супроводжують навчально-виховний процес вузів, несуть загрозу стабільності їх функціонування, сприяють проявам педагогічних ризиків.

Узагальнення позицій вітчизняних і зарубіжних дослідників дозволяють нам виділити риси, що впливають на прояв педагогічної толерантності у поведінці та діяльності майбутнього логопеда. До них належать:

- гуманність як увага і повага до самобутнього внутрішнього світу іншої людини, віра в іï добрі наміри, людяність міжособистісних відносин, відмова від методів примусу і форм придушення гідності людини;

- рефлексивність як глибоке знання особистістю власних особливостей, переваг та недоліків, їх відповідності толерантному ставленню до оточуючих, світосприйняття у цілому;

- незалежність, впевненість у собі як наявність самоповаги і самодисципліни, неприйнятті насильницьких інструкцій і заборон, способів діяльності; як адекватна оцінка власних сил і здібностей, віра в можливість подолати перешкоди ненасильницькими засобами;

- відповідальність як прояв внутрішньої сили в ситуації прийняття рішення, його якісного виконання на основі варіативного підходу й системи особистих вимог;

- гнучкість, багатовимірний та ймовірнісний підхід як уміння приймати рішення в залежності від складу учасників подій і обставин, їх можливостей та інтересів i обставин, що склалися; відсутність категоричності суджень, здатність не судити інших;

- самовладання та емпатійність як співпереживання проблем інших людей, емоційна оцінка подій; як володіння собою, управління емоціями, вчинками, незважаючи на ситуацію;

- почуття гумору як іронічне ставлення до безглуздих обставин, непродуманих дій, вміння посміятися над собою .

Сьогодні толерантність як готовність і здатність людини жити і конструктивно діяти у різноманітному і мінливому світі розглядається стратегічною метою сучасної освіти. Її досягнення неминуче вимагає особистісного підходу, бо основу толерантності складає самовизначення і особистісний вибір. Для майбутніх логопедів вона стає особливою якістю, якої вони набувають не завдяки накопиченню професійних знань, умінь і навичок, оволодіння компетентностями, а власними зусиллями у виборі життєвих і професійних цінностей.

Зазначимо, що спрямованість особистості на певні цінності і складає їі ціннісні орієнтації. Вони виступають у якості життєвих цілей та основних засобів їх досягнення і тому мають функцію важливих регуляторів соціальної поведінки, складають основу ставлення до інших людей, самого себе, основу світогляду (Мерлін, 1996).

Досліджуючи особливості репрезентації толерантності у системі цінностей та ціннісних орієнтацій студентів - майбутніх логопедів, ми зосередилися на 3'ясуванні питання про міру актуалізованості у свідомості студентів комплексу толерантних цінностей: спілкування (вихованість, життерадісність, терпимість, чесність); альтруїстичних (терпимість, чуйність); цінностей прийняття (самоконтроль, терпимість, чуйність, широта поглядів, чесність). Ми виходимо 3 того, що за рівнем актуалізованості толерантності як комплексної цінності можна судити про сформованість та міру усвідомлення сенсу толерантності майбутніми логопедами. 3 огляду на це зазначимо, що саме у становленні системи ціннісних орієнтацій важлива роль відводиться інструментальній толерантності (терпимості як відношенню) та специфічно професійній, яка пов'язана зі становленням толерантної свідомості майбутнього логопеда. У цьому випадку толерантність входить до складу смислових одиниць професійної свідомості, яка характеризується здатністю суб'єкта до ціннісносмислового самовизначення, до рефлексії способу свого існування. Ми підтримуємо 
думку, що для конструктивної взаємодії особливу роль толерантність відіграє саме як інструментальна цінність (Белинская, 2002).

Формування толерантності не повинно обмежуватися опануванням понять «толерантність», «толерантна людина». Як показало наше дослідження, майбутні логопеди добре орієнтуються у визначенні цих понять, але в недостатньому рівні реалізують їх зміст. На нашу думку, важливо сформувати у них толерантність щодо себе, передусім почуття гідності та здатності до самопізнання. Ці якості розглядаються у контексті групи, коли терпиме ставлення до себе $\epsilon$ необхідною умовою толерантності стосовно інших.

Загалом, як свідчать отримані нами дані, серед найбільш вагомих факторів у процесі підготовки майбутніх фахівців спеціальної освіти слід відзначити особливості особистісної сфери вчителя-логопеда, а саме: 57\% опитаних зазначили, що це любов до дітей, професіоналізм, доброта, творчість, толерантність, мобільність, компетентність, організованість, соціальна активність; 19\% зазначили, що вчительлогопед повинен мати високий рівень культури, повагу до дитини, врівноваженість, працелюбність гуманність, наполегливість, знання психологічних особливостей дітей; $24 \%$ респондентів вважають, що це милосердя, уміння знайти підхід до дитини, зацікавленість у роботі, бажання постійно вдосконалюватися, сприймати дитину такою як вона є, мати хороший науково-методичний рівень.

Bci $100 \%$ опитаних є одностайними, що базовою якістю виступає готовність допомогти дітям 3 психофізичними та мовленнєвими порушеннями у розкритті їхніх можливостей. Цінними якостями вчителя-логопеда, на думку респондентів, $\epsilon$ педагогічний оптимізм, милосердя, дотримання етичних норм, спостережливість, терпимість, толерантність.

Таким чином, зважаючи на комплексний характер педагогічної толерантності, ми визначили групу цінностей майбутніх логопедів, які утворюють інструментальний блок толерантної спрямованості особистості: терпимість, відповідальність, вихованість, життерадісність, самоконтроль, незалежність, чуйність, широта поглядів, непримиренність до недоліків. На нашу думку, цей комплекс цінностей, з одного боку, постає як деякий поведінковий орієнтир, який актуально та відповідно з певним станом особистості й обставинами ¥ї життєдіяльності реалізує іiі активність у конструктивно-толерантному напрямі, а 3 іншого, включає такі соціальні й етичні цінності, що виступають для майбутніх логопедів засобами досягнення стратегічних життєвих цілей, їх переконаннями в тому, що толерантному способу поведінки слід надавати перевагу в будь-якій ситуації.

Висновки та перспективи подальших розвідок. Отже, втілення в життя гуманістичних ідей, моралі, прав людини, людської гідності, чесності, милосердя, доброти й громадянської відповідальності нерозривно пов'язане із розвитком та формуванням толерантного ставлення до дітей 3 особливими потребами у майбутніх логопедів, які як майбутня інтелектуальна еліта країни можуть і повинні стати активними провідниками ідей толерантності, гарантуючи цим стабільний розвиток суспільства.

Подальші наші дослідження будуть спрямовані на діагностику сформованості толерантного ставлення до дітей з особливими потребами у майбутніх логопедів.

\section{СПИСОК ВИКОРИСТАНИХ ДЖЕРЕЛ}

Исаева, О., Комаров, В. (2003). Воспитание толерантности. Методические материалы для преподавателей высшей школы. Оренбург: ОГУ. 68 с.

Реан, А. (1999). Сочиальная педагогическая психология. СПб.: Питер. 410 с.

Клепцова, Е. (2004). Психология и педагогика толерантности. Москва: Академический проспект. 176 с.

Вульфов, Б. (2002). Воспитание и толерантность: сущность и средства. Воспитание и дополнительное образование детей и молодежи, 6(2). С. 5-10. 
Тодоровцева, Ю. (2004). Педагогіка толерантності. Методичні рекомендації. Одеса: Черкасов М. 90 с.

Ірхіна, Ю. (2009). Формування толерантності як складової підготовки магістрантів до професійно-педагогічної діяльності. В: Міжнародній конференції Освіта $i$ наука в умовах глобальних викликів. Сімферополь: Судак: Аріал. С.76-78.

Білоус, Т. (2004). Виховання толерантності в студентів вищих педагогічних навчальних закладів у прочесі вивчення іноземної мови. Київ: Либідь. 20 с.

Мерлин, В. (1996). Психология индивидуальности. Воронеж: НПО МОДЭК. 446 с.

Белинская, Е. (2002). Система ценностей личности в перспективе толерантности. Москва: МГУ. 72 с.

\title{
REFERENCES
}

Isayeva, O. \& Komarov, V. (2003). Vospitaniye tolerantnosti [Formation of Tolerance]. Metodicheskiye materialy dlya prepodavateley vysshey shkoly. Orenburh: OHU. 68 s. (in Russian)

Rean, A. (1999). Sotsyalnaya pedagogicheskaya psikholohyia [Social Pedagogical Psychology]. SPb.: Piter. 410 s. (in Russian)

Kleptsova, E. (2004). Psikhologyia $i$ pedagogika tolerantnosti [Psychology and Pedagogy of Tolerance]. Moskva: Akademicheskiy prospekt. 176 s. (in Ukrainian)

Vulfov, B. (2002). Vospitaniye i tolerantnost: sushchnost i sredstva [Education and Tolerance: Essence and Tools]. Vospitaniye i dopolnitelnoye obrazovaniye detei i molodezhy, 6 (2), S. 5-10. (in Russian)

Todorovtseva, Yu. (2004). Pedahohika tolerantnosti [Pedagogy of Tolerance]. Metodychni rekomendatsii. Odesa: Cherkasov M. 90 s. (in Ukrainian)

Irkhina, Yu. (2009). Formuvannia tolerantnosti yak skladovoi pidhotovky mahistrantiv do profesiino-pedahohichnoi diialnosti [Formation of Tolerance as a Component of training of Undergraduates for Professional and Pedagogical Activity]. V: Mizhnarodnii konferentsii Osvita $i$ nauka $v$ umovakh hlobalnykh vyklykiv. Simferopol: Sudak: Arial. S.76-78. (in Ukrainian)

Bilous, T. (2004). Vykhovannia tolerantnosti $v$ studentiv vyshchykh pedahohichnykh navchalnykh zakladiv u protsesi vyvchennia inozemnoi movy [Formation of Tolerance in Students of Higher Pedagogical Institutions in the Process of Learning a Foreign Language]. Kyiv: Lybid. 20 s. (in Ukrainian)

Merlin, V. (1996). Psikhologiya individualnosti [Psychology of Individuality]. Voronezh: NPO MODEK. 446 s. (in Russian)

Belinskaya, E. (2002). Sistema tsennostei lichnosti v perspektive tolerantnosti [The System of Personality Values in the Perspective of Tolerance]. Moskva: MHU. 72 s. (in Russian)

\section{FORMATION OF TOLERANT ATTITUDE TOWARDS CHILDREN WITH SPECIAL NEEDS IN FUTURE SPEECH THERAPISTS}

\author{
Halyna Kosarieva \\ Candidate of Pedagogical Sciences, \\ Associate Professor at the Department of Pedagogy \\ and Psychology (Preschool and Correctional) \\ named after Professor T.Ponimanska, \\ Rivne State University for the Humanities, \\ Rivne, Ukraine \\ ORCID: 0000-0002-1999-5787 \\ e-mail: galochka0961@gmail.com
}

\footnotetext{
Abstract. In order to motivate research into the problem of forming a tolerant attitude towards children with special needs in future speech therapists, the essence of pedagogical
} 
tolerance is revealed as a characteristic of the professional activity of the future specialist of special education. The role of the professional competence of the future teacher in the formation of the specified quality is determined. It is stated that the values and tolerance of the future teacher form the basis of professional competence, and the subject field of values and tolerance formation is culture. The experience of foreign researchers and different approaches of domestic scientists to form the future speech therapist of charity, tolerance, humility, honesty, kindness, humanity and attitude to a child with special needs who have no condemnation but have compassion, empathy, understanding of human values help. The importance of pedagogical tolerance for modern pedagogical science is highlighted. The place of tolerance in the system of humanistic values was determined, the main features of the tolerant teacher were singled out. On the basis of the general results of the research, the professional and personal traits of the future speech therapist are distinguished, influencing the formation of a tolerant attitude towards children with special needs: humanity as attention and respect for the original inner world of another person; reflexivity; independence, selfconfidence as self-esteem and self-discipline; responsibility as a manifestation of inner strength in the decision-making situation; flexibility, multidimensional and probabilistic approach as the ability to make decisions depending on the composition of participants of events and circumstances; lack of categorical judgment, ability to not judge others; selfcontrol and empathy as empathy for other people's problems; sense of humor as an ironic attitude to senseless circumstances, ill-considered actions, the ability to laugh at yourself.

Keywords: tolerance, pedagogical tolerance, forming of tolerance, tolerant attitude, children with special needs, humanity, charity, future speech therapists, universal values.

Стаття надійшла до редакиії 27.09.2019 р 